\title{
A STUDY TO UNDERSTAND FACTORS AFFECTING SOCIAL NETWORK USAGE $^{1}$
}

\author{
Sosyal Ağ Kullanımını Etkileyen Faktörleri Anlamaya Yönelik Bir Araştırma \\ Dr. Kemal ELCIYAR ${ }^{1}$ \\ Anadolu University, Communication Design and Management \\ D) 0000-0002-7820-2978
}

\begin{abstract}
Users may join social networks (SNS) for many personal or professional purposes. While many individuals voluntarily join SNS, for some, this may also be a form of forced use. However, in both cases there are some factors that influence SNS use. This research uses Technology Acceptance Model and includes trust and satisfaction factors and the technical aspects of SNS. Data collected from university students by survey technique was analyzed. As a result; the research model has good fit indices, and the factors in the model have relationships of varying strengths and significance with each other. Trust in SNS positively affects the continuance intention to SNS. However, the relationship between trust in others and the continuance intention did not turn out as predicted. Informativeness affects both perceived usefulness and perceived enjoyment constructs in a positive and significant way. While interactivity significantly affects perceived usefulness, there is no significant relationship between it and perceived enjoyment. There are also positive and significant relationship between satisfaction, intention, perceived usefulness and perceived enjoyment.
\end{abstract}

Key Words: SNS, Trust, TAM

Öz: Kullanıcılar sosyal ağlarda çeşitli kişisel veya profesyonel amaçlarla yer alabilirler. Birçok birey sosyal ağlarda gönüllü kullanıılar olarak yer alıp katılım gösterirken, kimi kullanıcıları zorlayan daha farklı durumlar olabilmektedir. iki tür katılım ve kullanım sürecini de etkileyen faktörler bulunmaktadır. Bu araştırma, Teknoloji Kabul Modeli'ni kullanmakta ancak buna tatmin, güven ve teknik bazı boyutları eklemektedir. Araştrrmada üniversite öğrencilerinden anket tekniği ile toplanan veriler analiz edilmiştir. Sonuçlara göre araştırma modeli iyi bir uyum göstermektedir. Modelde yer alan faktörler birbirleriyle çeşitli güçlerde ilişkilere sahiptir. Sosyal ağlara yönelik kullanıcıların duyduğu güven, bu ağları kullanımı olumlu etkilerken; bu ağlarda yer alan diğer kullanıcılara olan güven beklendiğinin aksine olumsuz bir etkiye sahiptir. Bilgilendiriciliğin algılanan fayda ve algılanan haz üzerinde ise olumlu yönlü bir etkisi vardır. Bu ağların etkileşimli yapısını ön plana çıkaran kullanıılar ise algılanan faydaları ön plana çıkarmaktadır. Ayrıca bu ağlardan alınan tatmin ile devamlııı niyeti, algılanan fayda ve algılanan haz arasında da olumlu ilişkiler elde edilmiştir.

Anahtar Kelimeler: Sosyal Ağlar, Güven, Teknoloji Kabul Modeli

\footnotetext{
${ }^{1}$ Makalenin Türü: Araştırma Makalesi

2 e-mail: kemalelciyar@anadolu.edu.tr
} 


\section{INTRODUCTION}

Many people widely use SNS for purposes such as connecting with each other, expressing themselves, keeping up to date, posting their own photos (Poushter, Bishop and Chwe, 2018; Statista, 2018). Because these sites are based on interaction and participation, users play a key role in the success of these sites (Wei, Lin, Lu and Chuang, 2014, p.151). Bhattacherjee (2001) states that satisfaction and expectations are important factors in the continuance of information systems. Through social activities, individuals can create perceived benefits and gains (Helliwell and Putnam, 2004). Trust is another important factor that plays a role in an individual's intention to perform a behavior (McKnight, Choudhurty and Kacmar, 2002). When evaluating trust, it is possible to go to a dual separation; interpersonal and institutional (Han, 2012). Institutional trust is the user's trust for the system, while interpersonal trust is trust for other users. In addition, "TAM" developed by Davis, Bagozzi and Warshaw $(1989$, p.983) explained the continuity of use through perceived ease of use and perceived usefulness. Then the perceived enjoyment was added to this model (Davis, Bagozzi and Warshaw, 1992). The research, which also investigates technical factors along with the trust, aims to explain the use of social networking. To explain the continuance intention, these factors are related to each other. In this context, the study tries to explain the factors affecting the users' intention to use SNS. Particularly to examine young's who are active users of SNS and to make a differentiation.

\section{Theoretical Framework and Hypotheses}

\subsection{Trust}

Trust refers to an individual's belief or expectation in the ethical behavior of others under various factors such as subjective norms, risk and safety (Grandison and Sloman, 2000 cited in Chang, Liu, and Shen, 2017, p.208). It is also a determinant in the interaction and behavior of individuals (Gefen, Karahanna and Straub, 2003, p.55). Trust in technology is the belief of users that technology has desirable characteristics to protect their own concerns. Through these features, users are willing to stay connected to the system (McKnight, 2005).

Hypotheses 1a: Trust in SNS has a positive relationship with intention to use Hypotheses 1b: Trust in other users in SNS has a positive relationship with intention to use

\subsection{Informativeness}

SNS are source of news and information for users. This highlights the willingness to obtain information, which is another motivation for using SNS. SNS can offer individuals a variety of information, trends, interesting news (Shi, Lee, Cheung and Chen, 2010, p.2). In this respect, information is essential for the continuance intention of SNS (Chen, 2012).

Hypotheses 2a: Informativeness has a positive relationship with perceived usefulness Hypotheses $2 \mathrm{~b}$ : Informativeness has a positive relationship with perceived enjoyment

\subsection{Interactivity}

"By adding interaction to a website, it is possible to develop positive attitudes of users" (Rafaeli, 1988 cited in Lu, Lin, Hsiao and Cheng, 2010, p.403). The ability to interact are the most distinctive features of today's web tools such as SNS.

Hypotheses 3a: Interactivity has a positive relationship with perceived usefulness Hypotheses $3 \mathrm{~b}$ : Interactivity has a positive relationship with perceived enjoyment 


\subsection{Satisfaction}

User satisfaction refers to the degree to which a user is satisfied with its overall experience with an information community. Satisfaction with the use of this product or service determines users' continuance intention for using a service. (Oliver, 1980 cited in Bhattacherjee, 2001, p.353).

Hypotheses 4: Satisfaction has a positive relationship with the intention to use

\subsection{Perceived Usefulness}

Users may use an information system and this system may provide a performance boost for the user to achieve his goals. This factor is derived from TAM. The perceived usefulness influences the acceptance of users by the results that support the value of the outputs (Davis et al., 1989). The perceived usefulness is that the social media user's use of a particular SNS helps him meet some goal drive needs.

Hypotheses 5: Perceived usefulness has a positive relationship with satisfaction

\subsection{Perceived Enjoyment}

Davis et al. then added the perceived enjoyment to TAM (1992). When users find a system enjoyable, they are more motivated to continuance intention. SNS have utilitarian purposes and a hedonistic perception in users (Lenhart and Madden, 2007 cited in Sledgianowski and Kulviwat, 2009, p.76).

Hypotheses 6: Perceived enjoyment has a positive relationship with satisfaction

\subsection{Continuance Intention}

In the context of information technology, continuance intention may be seen as decisions by user's intention to use an information system (Bhattarcherjee, 2001, p.353). It expresses the intention to use a service.

\section{Methodology}

\subsection{Participants}

This research applied to undergraduate students. Data were collected from the faculties in December 2019 with random sampling technique in Anadolu University. After evaluating mahalanobis distance, there were 507 available data; 250 female; 257 male.

\subsection{Materials}

Some factors of Han's model have been used in accordance with research objectives: trust (Han and Windsor, 2011), informativeness (Shi et al., 2010), interactivity (Wu and Chang, 2005), satisfaction (Bhattacherjee, 2001), continuance intention (Bhattacherjee, 2001), perceived usefulness (Limayem, Hirt and Cheung, 2007), perceived enjoyment (Van der Heijden, 2004). Which studies Han adapted the scale factors from are also given in parentheses. In this context, participants were expected to respond to the 5-point Likert-type expressions which were classified as strongly disagree to strongly agree. For the study, Harman's single factor test was applied to deal with common method bias. According to the results, one factor explains $35 \%$ of the variance and this is also acceptable.

Research results can be generalized to their own sample, and research can also be applied to groups with different demographics. The fact that the research is cross-sectional is also a limitation. Limitations are discussed in a little more detail in the conclusion. 


\section{Results}

\subsection{Measurement Model}

Table 2 shows the AVE value and composite reliability (CR). In the study, all AVE values are above 0.40 which indicate good convergent validity of the instrument. All CR values are above 0.70 (Fornell and Larcker , 1981).

Table 1: Summary of the confirmatory factor analysis

\begin{tabular}{|c|c|c|c|}
\hline Factors & Loadings & Critical ratio & St. Error \\
\hline Trust in SNS & 0.70 & & \\
\hline$C R=\quad 0,836$ & 0.65 & 13.18 & 0.072 \\
\hline \multirow[t]{2}{*}{$A V E=0,564$} & 0.82 & 16.41 & 0.066 \\
\hline & 0.82 & 16.36 & 0.063 \\
\hline Trust in Other Members & 0.87 & & \\
\hline$C R=0,881$ & 0.87 & 24.11 & 0.042 \\
\hline$A V E=0,712$ & 0.79 & 21.03 & 0.042 \\
\hline Perceived Enjoyment & 0.72 & & \\
\hline$C R=0,867$ & 0.84 & 18.15 & 0.059 \\
\hline \multirow[t]{2}{*}{$A V E=0,622$} & 0.83 & 17.80 & 0.063 \\
\hline & 0.76 & 16.33 & 0.061 \\
\hline Perceived Usefulness & 0.76 & & \\
\hline$C R=0,853$ & 0.78 & 17.46 & 0.058 \\
\hline \multirow[t]{2}{*}{ AVE $=0,593$} & 0.76 & 16.90 & 0.057 \\
\hline & 0.78 & 17.52 & 0.052 \\
\hline Continuance Intention & 0.77 & & \\
\hline$C R=0,851$ & 0.84 & 19.19 & 0.053 \\
\hline AVE $=0,656$ & 0.82 & 18.62 & 0.062 \\
\hline Informativeness & 0.68 & 16.67 & 0.043 \\
\hline$C R=0,749$ & 0.74 & 18.56 & 0.042 \\
\hline AVE $=0,500$ & 0.70 & 17.33 & 0.041 \\
\hline Interactivity & 0.73 & & \\
\hline$C R=0,842$ & 0.75 & 15.82 & 0.062 \\
\hline \multirow[t]{2}{*}{ AVE $=0,572$} & 0.84 & 17.40 & 0.063 \\
\hline & 0.70 & 14.65 & 0.063 \\
\hline Satisfaction & 0.76 & & \\
\hline$C R=0,890$ & 0.88 & 20.40 & 0.057 \\
\hline \multirow[t]{2}{*}{ AVE $=0,672$} & 0.88 & 20.38 & 0.057 \\
\hline & 0.75 & 17.15 & 0.067 \\
\hline
\end{tabular}

In the research, confirmatory factor analysis was performed to test the measurement model. The fit indices of the measurement model were evaluated by the various indices provided by the Lisrel. The ratio of $\mathrm{x} 2$ / df (chi square/degrees of freedom $=909,42 / 349$ ) was used and a value of 2.60 was obtained. There are studies argued that $x 2 / d f$ should be at most 3 (Kline, 1998), at most 2 (Ullman, 2001), while others indicate that they can 
have a maximum value of 5 (Chahal and Kumari, 2011; Schumacker and Lomax, 2004). In addition, other indices were found as follows: GFI value 0.89; CFI value 0.94; AGFI 0.86; NFI 0.90; TLI 0.92. Other important indices are; root mean square residual value 0.050 . Besides, the value of RMSEA is 0.056 . In the context of CFI, NFI, AGFI, TLI and RMSEA values, the measurement model has a good fit. RMSEA describes the discrepancy between the proposed model and the population covariance matrix. As shown in Table 4, the model meets the cut off value (0.10) specified by Steiger (1990) with a value of 0.056. Hair, Anderson, Tatham and Black (1998) advocates goodness of fit to be greater than 0.90. Hooper, Coughlan and Mullen (2008) also advocates the same value; generally accepted that values of 0.90 or greater indicate well-fitting models. However, goodness-of-fit was found to be slightly below 0.90 .

Table 2: Question items and Cronbach's alpha reliability

\begin{tabular}{|c|c|c|c|c|}
\hline & $\begin{array}{l}\text { Factor } \\
\text { Means }\end{array}$ & $\begin{array}{r}\text { Item } \\
\text { Means }\end{array}$ & $\begin{array}{l}\text { Cronbach's } \\
\text { alpha }\end{array}$ & Questionnaire Items \\
\hline \multirow[t]{4}{*}{ Trust in SNS } & 2.57 & 2.76 & 0.83 & $\begin{array}{l}\text { I believe the social network site has the safety } \\
\text { of my privacy } \\
\text { information in mind }\end{array}$ \\
\hline & & 2.85 & & $\begin{array}{l}\text { The social network site only allows authorized } \\
\text { users to access to my information. }\end{array}$ \\
\hline & & 2.48 & & $\begin{array}{l}\text { The social network site keeps the information I } \\
\text { received and shared } \\
\text { reliable. }\end{array}$ \\
\hline & & 2.20 & & The social network site is trustworthy. \\
\hline \multirow[t]{3}{*}{ Trust Others } & 2.12 & 2.07 & \multirow{3}{*}{0.88} & $\begin{array}{l}\text { I feel other members of the social network site } \\
\text { are generally honest. }\end{array}$ \\
\hline & & 2.15 & & $\begin{array}{l}\text { I feel other members of the social network site } \\
\text { are generally reliable. }\end{array}$ \\
\hline & & 2.14 & & $\begin{array}{l}\text { I feel the identities that other members } \\
\text { profiled on the social network site are genuine. }\end{array}$ \\
\hline \multirow[t]{4}{*}{ P. Enjoyment } & 3.36 & 3.21 & \multirow{4}{*}{0.86} & The social network site is interesting to me. \\
\hline & & 3.64 & & Using the social network site is enjoyable. \\
\hline & & 3.41 & & I have a lot of fun on the social network site. \\
\hline & & 3.18 & & $\begin{array}{l}\text { Using the social network site brings me a } \\
\text { pleasant experience. }\end{array}$ \\
\hline \multirow[t]{4}{*}{ P. Usefulness } & 3.21 & 3.04 & \multirow{4}{*}{0.85} & $\begin{array}{l}\text { Using the social network site is of benefit to } \\
\text { me. }\end{array}$ \\
\hline & & 3.20 & & Using the social network site is advantageous. \\
\hline & & 3.10 & & $\begin{array}{l}\text { The advantage of using the social network site } \\
\text { outweighs the disadvantage. }\end{array}$ \\
\hline & & 3.48 & & The social network site is useful to me. \\
\hline
\end{tabular}




\begin{tabular}{|c|c|c|c|c|}
\hline \multirow[t]{3}{*}{$\begin{array}{l}\text { Continuance } \\
\text { Intention }\end{array}$} & 3.57 & 3.57 & \multirow{3}{*}{0.85} & $\begin{array}{l}\text { I intend to continue using the social network } \\
\text { site rather than discontinue its use. }\end{array}$ \\
\hline & & 3.87 & & $\begin{array}{l}\text { I will keep using the social network site in the } \\
\text { future. }\end{array}$ \\
\hline & & 3.26 & & $\begin{array}{l}\text { I have a strong intention to continue using the } \\
\text { social network site. }\end{array}$ \\
\hline \multirow[t]{3}{*}{ Informativeness } & 3.94 & 3.74 & \multirow{3}{*}{0.79} & $\begin{array}{l}\text { I am able to find interesting topics on the social } \\
\text { network site. }\end{array}$ \\
\hline & & 4.03 & & $\begin{array}{l}\text { I am able to check my family members' status } \\
\text { updates on the social network site. }\end{array}$ \\
\hline & & 4.05 & & $\begin{array}{l}\text { I am able to follow popular topics in the society } \\
\text { on the social network site. }\end{array}$ \\
\hline \multirow[t]{4}{*}{ Interactivity } & 2.92 & 3.04 & \multirow{4}{*}{0.84} & $\begin{array}{l}\text { Other people and I frequently share } \\
\text { information on this social network site. }\end{array}$ \\
\hline & & 2.90 & & $\begin{array}{l}\text { Other people and I rapidly respond to each } \\
\text { other's status update on this social network } \\
\text { site. }\end{array}$ \\
\hline & & 2.95 & & $\begin{array}{l}\text { Other people and I share a lot of information } \\
\text { on this social network site. }\end{array}$ \\
\hline & & 2.76 & & $\begin{array}{l}\text { Other people and I frequently make comments } \\
\text { on each other's shared topics on this social } \\
\text { network site. }\end{array}$ \\
\hline \multirow[t]{4}{*}{ Satisfaction } & 3.21 & 3.21 & \multirow{4}{*}{0.88} & Very satisfied/ Very dissatisfied. \\
\hline & & 3.15 & & Very pleased/ Very displeased. \\
\hline & & 3.16 & & Very contented/ Very frustrated. \\
\hline & & 3.33 & & Absolutely delighted/Absolutely terrible. \\
\hline
\end{tabular}

Since model fit indices are acceptable, reliability analysis is applied. Cronbach's alpha was applied to measure instrument reliability. For the cut off value of Cronbach's alpha, opinions range from 0.79 to 0.88 (Bland and Altman, 1997; Nunnally and Bernstein, 1994). The alpha values of the research have a value above 0.75 and, in this respect, their reliability is good. Convergent validity can also be assessed by factor loadings from confirmatory factor analysis (Table 2). The factor loadings higher than 0.60 are significant. When factor loadings are statistically significant, convergent validity is also evaluated significant (Anderson and Gerbing, 1988).

\subsection{Structural Model}

Table 3: Fit indices for measurement model and structural model

\begin{tabular}{llll}
\hline Goodness-of-fit measure & Recommended Value & Structural Model & Measurement Model \\
\hline $\mathbf{x}^{2} /$ degree of freedom & $\leq 3$ & 2.98 & 2.60 \\
\hline Goodness-of-fit (GFI) & $\geq 0.90$ & 0.87 & 0.89 \\
\hline Adjusted goodness-of-fit (AGFI) & $\geq 0.80$ & 0.84 & 0.86 \\
\hline Normalized fit index (NFI) & $\geq 0.90$ & 0.88 & 0.90 \\
\hline
\end{tabular}




\begin{tabular}{llcc}
\hline Tucker Lewis index (TLI) & $\geq 0.90$ & 0.91 & 0.94 \\
\hline Comparative fit index (CFI) & $\geq 0.90$ & 0.92 & 0.98 \\
\hline RMSEA & $\leq 0.10$ & 0.062 & 0.056 \\
\hline RMR & $\leq 0.10$ & 0.083 & 0.050
\end{tabular}

The fit indices of the structural model were also discussed with the various indices (Table 4) provided by the AMOS. The ratio of $x 2 / d f$ (chi square/degrees of freedom $=1071,35 / 360$ ) was used and a value of 2.98 was obtained. Also, other indices have found as follows: GFI value 0.87; CFI value 0.92; AGFI 0.84; NFI 0.88; TLI 0.91. Other important indices are RMR value has found as 0.083 and RMSEA is 0.062 . In the context of these values, the model showed good fit. Besides, Table 5 shows whether hypotheses are supported.

Table 4: Results of hypotheses

\begin{tabular}{|c|c|c|c|c|c|}
\hline Hypothesis & Path & Std. coefficient & $\mathbf{p}$ & t-values & Result \\
\hline H1a & Trust in SNS > Intention & 0.50 & 0.000 & 5,587 & Supported \\
\hline H1b & $\begin{array}{c}\text { Trust in Others > } \\
\text { Intention }\end{array}$ & -0.21 & 0.008 & $-2,667$ & $\begin{array}{c}\text { Not } \\
\text { Supported }\end{array}$ \\
\hline $\mathrm{H} 2 \mathrm{a}$ & $\begin{array}{c}\text { Informativeness }>\text { P. } \\
\text { Usefulness }\end{array}$ & 0.78 & 0.000 & 9,568 & Supported \\
\hline $\mathrm{H} 2 \mathrm{~b}$ & $\begin{array}{c}\text { Informativeness > P. } \\
\text { Enjoyment }\end{array}$ & 0.80 & 0.000 & 9,831 & Supported \\
\hline H3a & $\begin{array}{c}\text { Interactivity > P. } \\
\text { Usefulness }\end{array}$ & 0.12 & 0.025 & 2,234 & Supported \\
\hline H3b & $\begin{array}{c}\text { Interactivity > P. } \\
\text { Enjoyment }\end{array}$ & 0.10 & 0.081 & 1,744 & $\begin{array}{c}\text { Not } \\
\text { Supported }\end{array}$ \\
\hline H4 & Satisfaction > Intention & 0.50 & 0.000 & 8,470 & Supported \\
\hline H5 & $\begin{array}{c}\text { P. Usefulness > } \\
\text { Satisfaction }\end{array}$ & 0.17 & 0.026 & 2,220 & Supported \\
\hline H6 & $\begin{array}{l}\text { P. Enjoyment > } \\
\text { Satisfaction }\end{array}$ & 0.45 & 0.000 & 5,871 & Supported \\
\hline \multicolumn{2}{|c|}{ Indirect effects } & \multicolumn{2}{|c|}{ Std. coefficient } & $\mathbf{p}$ & Result \\
\hline \multicolumn{4}{|c|}{ Informativeness > P. Usefulness > Satisfaction } & 0,075 & Not Supported \\
\hline \multicolumn{2}{|c|}{ Informativeness $>$ P. Enjoyment $>$ Satisfaction } & \multicolumn{2}{|c|}{0,374} & $0,002 * *$ & Supported \\
\hline \multicolumn{2}{|c|}{ Interactivity $>$ P. Enjoyment $>$ Satisfaction } & \multicolumn{2}{|c|}{0,053} & 0,178 & Not Supported \\
\hline \multicolumn{2}{|c|}{ Interactivity > P. Usefulness > Satisfaction } & \multicolumn{2}{|c|}{0,025} & 0,099 & Not Supported \\
\hline P. Enjoymen & Satisfaction > Intention & 0,2 & & $0,022 *$ & Supported \\
\hline P. Usefulnes & Satisfaction > Intention & 0,0 & & $0,046^{*}$ & Supported \\
\hline
\end{tabular}


When the developed hypotheses were tested, some were supported and some were not. Trust in SNS positively affects the continuance intention to SNS $(\beta=0.50, p=0.000)$. The relationship between trust in others and the continuance intention to SNS did not turn out as predicted, and there is a negative relationship ( $\beta=$ $-0.21, p=0.008)$. Informativeness affects both perceived usefulness $(\beta=0.78, p=0.000)$ and perceived enjoyment $(\beta=0.80, p=0.000)$ constructs in a positive and significant way. While interaction significantly affects perceived usefulness $(\beta=0.12, p=0.025)$, there is no significant relationship between it and perceived enjoyment $(\beta=0.10$, $p=0.081)$. Satisfaction from SNS positively affects the continuance intention to SNS $(\beta=0.50, p=0.000)$. Finally, perceived usefulness $(\beta=0.50, p=0.000)$ and perceived enjoyment $(\beta=0.45, p=0.000)$ positively affect satisfaction from SNS. Also, SEM offers indirect effects as well as direct effects in created models. In the results related to indirect effects, informativeness, interactivity, perceived enjoyment and perceived usefulness factors appear to have effects on satisfaction and continuance intention. These values are in Table 5. Informativeness indirectly affects satisfaction positively $(\beta=0.374, p=0.002)$. In addition, perceived enjoyment $(\beta=0.205, p=0.022)$ and perceived usefulness $(\beta=0.075, p=0.046)$ indirectly and significantly affect continuance intention.

\section{DISCUSSION}

As mentioned, perceived enjoyment and perceived usefulness have a significant relationship with satisfaction. In this respect, participants may state that SNS give them joy, and there is a relationship related to benefit that will affect their satisfaction. Users also continue to use the systems they enjoy (Heijden, 2004; Shipps and Philips, 2013; Sun, Liu, Peng, Dong and Barnes 2014). Similar results are also seen in this study. Bhattacherjee (2001, p.356) also stated in his research that satisfaction has relation with perceived usefulness. In this study, perceived usefulness affects the satisfaction positively. There is also a positive relationship between satisfaction and continuance intention in other studies (Sun et al., 2014). The results of this study also show that when the satisfaction of users is high, their continuance intention to SNS is higher.

Trust for a website is a belief in the security mechanisms perceived to exist on the site (Gefen et al.,2003, p.51). Greater trust also has an increasing effect on the intention to use the website. Interpersonal trust takes place among users and significantly affects the intention of members to exchange information (Ridings, Gefen and Arinze, 2002, p.279). They will be more willing to interact if there is trust among each other. Their trust in each other is particularly important in terms of identifying voluntary behaviors. As seen in the results of the study, participants' trust in other members of SNS has the lowest score among all factors. In other words, the participants do not trust in the other users in SNS. There is a negative relationship between these factors. Institutional trust is the necessity of having mechanisms to enable SNS services to act in accordance with the positive expectations of the members. Users will be able to show an increased continuance intention if they trust the system of social networking (Sledgianowski and Kulviwat, 2009). As can be seen from research results, users trust more on the SNS than they trust other members of the SNS. Due to that, there is a positive and meaningful relationship between the users' continuance intention and trust towards the SNS. When users think that the SNS system is reliable, their usage is becoming more intense. 
Figure 1: Results of research model

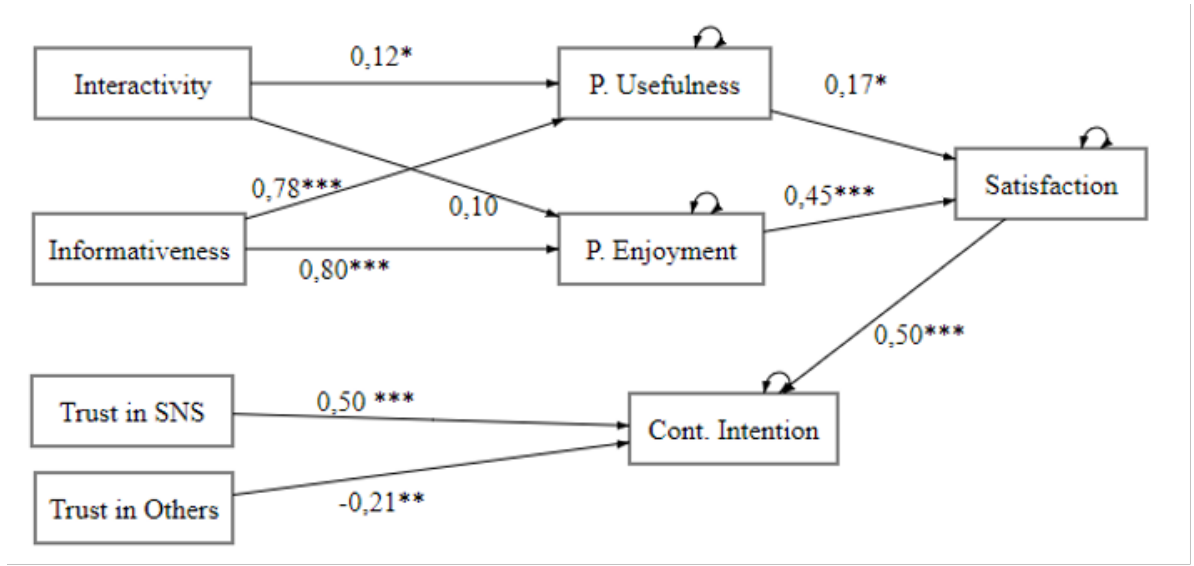

The features such as interaction, information sharing and support in SNS may affect users' perceived enjoyment and usefulness. The information they get from SNS can be support for users. People can interact, access events, use apps, play games. With these features the ability to interact in a SNS environment is one of the most distinctive features of today's web tools such as SNS. SNS are platforms in which people share information and resources, which can differ at the levels of trust and privacy, and host social interactions and relationships. It is also possible for users to gain acquisitions through interactivity and informativeness, such as collaboration and learning. Participants who think in this way also perceive higher joy and benefits from SNS.

\section{CONCLUSION}

The main purpose of the study was to evaluate the factors affecting the continuance intention to SNS. In order to examine the factors that affect the continuance intention of the use of these networks which seem to maintain their importance in the future, a model created by using TAM, mostly technical aspects of SNS, trust and satisfaction.

The contribution of the research can be stated as follows: first of all, in the research, the university students' usage, who can be seen as the most common users of SNS, discussed in more detail. The research also suggests a model for continuance intention to SNS, and also indicates the factors that affect and do not affect continuance intention. Satisfaction have a positive effect on the continuance intention. There was negative relationship between trust in other members of the SNS and continuance intention. Finally, when we interpret the results for service providers, the trust in SNS and members of the SNS are relatively low compared to other factors. Therefore, service providers need to increase their trust in the users. In addition, improvements in the system will improve the confidence of the users among each other, and this may positively affect the continuance of the network.

The research has limitations in terms of both methods and results. However, these limitations indicate avenues for further research. The research was carried out at a university in Turkey. Therefore, we cannot say that the results include other universities. In addition, the average age of the sample was 21 and we cannot explain the use of SNS in all age groups. With a broader sample and longitudinal studies can be done. We hope that our research will contribute to other studies to explain the continuity of the use of SNS with the features and results. 


\section{BIBLIOGRAPHY}

Al-Sharqi, L., Hashim, K., \& Kutbi, I. (2015). Perceptions of social media impact on students' social behavior: A comparison between Arts and Science students. International Journal of Education and Social Science, 2(4), 122-131.

Anderson, J. C., \& Gerbing, D. W. (1988). Structural equation modeling in practice: A review and recommended two-step approach. Psychological bulletin, 103(3), 411.

Bhattacherjee, A. (2001). Understanding information systems continuance: an expectation-confirmation model. MIS quarterly, 351-370.

Bland, J. M., \& Altman, D. G. (1997). Statistics notes: Cronbach9s alpha. Bmj, 314(7080), 572.

Chahal, H., \& Kumari, N. (2011). Consumer perceived value and consumer loyalty in the healthcare sector. Journal of Relationship Marketing, 10(2), 88-112.

Chang, S. E., Liu, A. Y., \& Shen, W. C. (2017). User trust in social networking services: A comparison of Facebook and Linkedln. Computers in Human Behavior, 69, 207-217.

Correa, T., Hinsley, A. W., \& De Zuniga, H. G. (2010). Who interacts on the Web?: The intersection of users' personality and social media use. Computers in Human Behavior, 26(2), 247-253.

Davis, F. D., Bagozzi, R. P., \& Warshaw, P. R. (1992). Extrinsic and intrinsic motivation to use computers in the workplace 1. Journal of applied social psychology, 22(14), 1111-1132.

Davis, F. D. (1989). Perceived usefulness, perceived ease of use, and user acceptance of information technology. MIS quarterly, 319-340.

Davis, F. D., Bagozzi, R. P., \& Warshaw, P. R. (1989). User acceptance of computer technology: a comparison of two theoretical models. Management science, 35(8), 982-1003.

Fornell, C., \& Larcker, D. F. (1981). Evaluating structural equation models with unobservable variables and measurement error. Journal of marketing research, 18(1), 39-50.

Gefen, D., Karahanna, E., \& Straub, D. W. (2003). Trust and TAM in online shopping: An integrated model. MIS quarterly, 27(1), 51-90.

Hair, J. J., Anderson, R., Tatham, R., \& Black, W. (1998). Multivariate data analysis (5thed.). NJ, United States: Prentice-Hall.

Han, B. (2012). An investigation of factors influencing the user's social network site continuance intention. University of North Texas.

Han, B. O., \& Windsor, J. (2011). User's willingness to pay on social network sites. Journal of computer information systems, 51(4), 31-40. 
Harris, J. A. (1993). Personalities of students in three faculties: Perception and accuracy. Personality and Individual Differences, 15(3), 351-352.

Helliwell, J. F., \& Putnam, R. D. (2004). The social context of well-being. Philosophical Transactions of the Royal Society B: Biological Sciences, 359(1449), 1435.

Hooper, D., Coughlan, J., \& Mullen, M. (2008). Structural equation modelling: Guidelines for determining model fit. Articles, 2.

Huang, C. C., Wang, Y. M., Wu, T. W., \& Wang, P. A. (2013). An empirical analysis of the antecedents and performance consequences of using the moodle platform. International Journal of Information and Education Technology, 3(2), 217.

Kline, R. B. (1998). Principles and practice of structural modeling. Guilford publications.

Kline, P., \& Lapham, S. L. (1992). Personality and faculty in British universities. Personality and Individual Differences, 13(7), 855-857.

Limayem, M., Hirt, S. G., \& Cheung, C. M. (2007). How habit limits the predictive power of intention: The case of information systems continuance. MIS quarterly, 705-737.

Lomax, R. G., \& Schumacker, R. E. (2004). A beginner's guide to structural equation modeling. Psychology press.

McKnight, D. H. (2005). Trust in information technology. The Blackwell encyclopedia of management, 7, 329-331.

McKnight, D. H., Choudhury, V., \& Kacmar, C. (2002). Developing and validating trust measures for e-commerce: An integrative typology. Information systems research, 13(3), 334-359.

Nunnally, J. C., \& Bernstein, I. H. (1994). Psychometric Theory (McGraw-Hill Series in Psychology) (Vol. 3). New York: McGraw-Hill.

Poushter, J., Bishop, C., \& Chwe, H. (2018). Social network adoption varies widely by country. Retrieved from Pew Research Center: http://www. pewglobal.org/2018/06/19/3-social-network-adoption-varieswidely-by-country.

Ridings, C. M., Gefen, D., \& Arinze, B. (2002). Some antecedents and effects of trust in virtual communities. The Journal of Strategic Information Systems, 11(3-4), 271-295.

Sharma, A., \& Jaswal, I. (2015). Personality and Patterns of Facebook Usage. International Journal of Academic Research in Psychology, Vol. 2, No. 2.

Shi, N., Lee, M. K., Cheung, C. M., \& Chen, H. (2010). The continuance of online social networks: how to keep people using Facebook?. In System sciences (HICSS), 2010 43rd Hawaii international conference on (pp. 1-10). IEEE. 
Shipps, B. \& Phillips, B. (2013). Social networks, interactivity and satisfaction: assessing socio-technical behavioral factors as an extension to technology acceptance. Journal of theoretical and applied electronic commerce research, 8(1), 35-52.

Sledgianowski, D., \& Kulviwat, S. (2009). Using social network sites: The effects of playfulness, critical mass and trust in a hedonic context. Journal of Computer Information Systems, 49(4), 74-83.

Statista (2018). Active social network penetration in selected countries as of January 2018. https://www.statista.com/statistics/282846/regular-social-networking-usage-penetration-worldwi de-by-country/

Sun, Y., Liu, L., Peng, X., Dong, Y., \& Barnes, S. J. (2014). Understanding Chinese users' continuance intention toward online social networks: an integrative theoretical model. Electronic Markets, 24(1), 57-66.

Ullman, J. B. (2001). Structural equation modeling. In B. G. Tabachnick \& L. S. Fidell (Eds.), Using multivariate statistics (4th ed.). Needham Heights, MA: Allyn \& Bacon.

Wei, H. L., Lin, K. Y., Lu, H. P., \& Chuang, I. H. (2015). Understanding the intentions of users to 'stick'to social networking sites: a case study in Taiwan. Behaviour \& Information Technology, 34(2), 151-162.

Wu, J. J., \& Chang, Y. S. (2005). Towards understanding members' interactivity, trust, and flow in online travel community. Industrial Management \& Data Systems, 105(7), 937-954.

Van der Heijden, H. (2004). User acceptance of hedonic information systems. MIS quarterly, 695-704. 